\title{
PENGARUH PENGGUNAAN MODUL GUIDED INQUIRY TERHADAP KEMAMPUAN BERPIKIR KRITIS MAHASISWA STIKES PERINTIS PADANG
}

\author{
Marisa*) \\ STIKes Perintis Padang \\ Email: marisaazzhila@yahoo.co.id \\ Lisa Fradisa \\ STIKes Perintis Padang \\ Email : lisafradisa99@yahoo.com
}

\begin{abstract}
Abstrak: This study aims to determine the effect of the use of guided inquiry learning modules on critical thinking skills of students and comparing critical thinking skills of students taught through guided inquiry learning modules and conventional learning models. This is an experimental research. The data of the research were obtained through a test, and observatio. The normality, homogeneity, and the difference between the two sets of data were computed using the SPSS 16.0 For Windows program. Questionnaire result data for each student is given a score according to a scale. Then, the average score per statement and the average total score were found out. The results showed that the guided inquiry learning module and conventional learning could significantly improve students' critical thinking skills and the improvement of critical thinking skills with the treatment of guided inquiry learning models was significantly better than conventional learning. And the results of students' activity in the experiment class are better than that in the control class.
\end{abstract}

Kata Kunci: Module, guided inquiry, critical thinking ability
PENDAHULUAN

$\mathrm{K}$ urikulum 2013menganut pandangan dasar bahwa pengetahuan tidak dapat dipindahkan begitu saja dari guru ke siswa. Kurikulum 2013 menuntut siswa supaya secara aktif mencari, mengolah dan mengonstuksi pengetahuan dalam proses pembelajaran (Permendikbud, 2013). Selain itu, kurikulum 2013 menuntut guru melaksanakan pembelajaran dengan menggunakan pendekatan saintifik sehingga dapat mendorong siswa lebih aktif secara individual atau kelompok dalam pembelajaran. Pendekatan saintifik sesuai dengan sintaks beberapa model pembelajaran yang salah satunya adalah model inkuiri.
Model pembelajaran inkuiri adalah suatu kegiatan pembelajaran yang menekankan pada proses berpikir kritis dan analitis untuk mencari serta menemukan sendiri jawaban dari suatu masalah yang berorientasi kepada siswa (student centered approach) (Sanjaya, 2006: 196-197). Salah satu tingkatan dari model pembelajaran inkuiri yaitu inkuiri terbimbing. Menurut Hanson (2005: 1), suatu kegiatan belajar yang menerapkan inkuiri terbimbing menggunakan siklus belajar yang terdiri dari 5 tahap yaitu orientasi, eksplorasi, penemuan konsep atau pembentukan konsep, aplikasi dan penutup. Model pembelajaran akan menghasilkan hasil belajar yang maksimal dan bermakna jika dalam proses 
pembelajarannya digunakan bahan ajar dengan model pembelajaran yang sama seperti bahan ajar berbasis inkuiri terbimbing. Berdasarkan hasil observasi di Sekolah Tinggi Ilmu Kesehatan (STIKes) Perintis Padang diperoleh kesimpulan bahwa untuk saat ini, belum terdapat bahan ajar berupa modul yang sesuai tuntutan kurikulum padamata kuliah Kimia Dasar. Bahan ajar yang tersedia (dalam bentuk buku paket dan LKS) belum berbasis pendekatan saintifik dan belum menggunakan model pembelajaran seperti yang dianjurkan dalam Kurikulum sehingga proses pembelajaran di kelas masih berpusat pada Dosen. Konsepkonsep pada materi ini dipaparkan dalam bahan ajar yang ada sehingga bahan ajar belum mampu mendukung mahasiswa untuk berpikir kritis dalam pencarian konsep (proses mencari tahu) yang mengakibatkan mahasiswa cenderung hanya menghafalkan konsep-konsep bukan memahami konsep secara utuh.Bahan ajar yang tersedia di lapangan juga kurang disajikan dengan baik.Hal ini dibuktikan dari penyajian materi atau konsep belum secara multiple representation terutama pada level submikroskopik.Materi dan konsep yang bersifat abstrak seharusnya disajikan secara submikroskopik sehingga siswa terpancing untuk berpikir dan bernalar dalam penemuan dan pemahaman konsep.Selain itu, penyajian secara multi representasi dapat membantu untuk menyajikan materi atau konsep yang bersifat abstrak menjadi dapat teramati.Bahan ajar yang tersedia juga belum didesain dengan baik.Hal ini dapat dilihat dari segi pemilihan warna, bahasa, dan tata letak.

Salah satu solusi yang dapat digunakan guru untuk mengatasi masalah di atas adalah bahan ajar kimia berbasis inkuiri terbimbing dalam bentuk modul.Penggunaan bahan ajar dalam bentuk modul diharapkan mampu menjadikan siswa lebih aktif, kreatif, semakin bisa mengembangkan diri, dan mampu membantu mahasiswa dalam menemukan konsepnya sendiri.Modul yang dikembangkan dilengkapi dengan multi representasi kimia yaitu makroskopik, submikroskopik, dan simbolik.Modul juga didesain dengan pemilihan warna, bahasa, dan tata letak yang disesuaikan dengan materi serta kebutuhan mahasiswa. Modul ini diharapkan mampu menuntun siswa dalam enemukan konsep sendiri, meningkatkan pemahaman terhadap materi dan melatih keterampilan berpikir tingkat tinggi mahasiswa.

Berdasarkan hasil penelitian sebelumnya yang dilakukan oleh Bilgin (2009) dan Myers (2012) disimpulkan bahwa siswa yang belajar dengan menggunakan strategi inkuiri terbimbing lebih mudah mengerti dan memahami konsep pelajaran serta meningkatkan efetivitas interaksi dan meningkatkan minat belajar melalui kerja kelompok yang sangat terstruktur. Sebelumnya telah dikembangkan Penelitian yang dilakukan Marisa (2017) dengan judul "Pengembangan Modul pembelajaran berbasis Guided Inquiry untuk meningkatkan motivasi dan hasil belajar pada Mata Kuliah Kimia Dasar di STIKes Perintis Padang. Berdasarkan uraian di atas, penulis merasa perlu melakukan penelitian untuk mengetahui pengaruh penggunaan bahan ajar dalam bentuk modul berbasis inkuiri terbimbing. Penelitian yang akan dilakukan berjudul "Pengaruh Penggunaan Modul Pembelajaran Guided Inquiry untuk meningkatkan kemampuan berpikir kritis pada Mata Kuliah Kimia Dasar”.

\section{METODE PENELITIAN}

Penelitian ini adalah penelitian eksperimen dengan desain Kelompok kontrol 
pretest-postest. Penelitian ini akan dilakukan di kampus STIKes Perintis Padang mulai dari April - November 2018. Data penelitian ini dikategorikan ebagai data primer karena diperoleh secara langsung dari mahasiswa yang diambil melalui soal pretes, dan lembar observasi.

Data hasil pretest - postest masingmasing kelas digunakan untuk menjawab rumusan masalah pertama dan kedua, sedangkan data hasil pretest dan postest kedua kelas digunakan untuk menjawab rumusan masalah ketiga. Data tersebut kemudian dilakukan uji normalitas, homogenitas, dan perbedaan dua rata - rata menggunakan program SPSS 16.0 For windows. Data hasil angket setiap mahasiswa diberi skor sesuai skalanya. Setelah itu, mencari rata - rataskor per pernyataan dan rata - rata skor totalnya.

Data hasil wawancara kemudian diolah untuk memperoleh respon mahasiswa. Angka yang diperoleh dari hasil observasi mahasiswa diolah menggunakan rumus perhitungan persentase kemudian hasilnya diinterprestasikan ke dalam kriteria sesuai dengan masing - masing data.

\section{HASIL DAN PEMBAHASAN}

\section{Hasil Berpikir Kemampuan Kritis}

Data penelitian ini diperoleh dari mahasiswa Prodi D III Analis Kesehatan Tingkat 1 yang berjumlah 83 mahasiswa. yang terdiri dari 42 mahasiswa kelas kontrol dan 41 mahasiswa kelas eksperimen. Data penelitian ini merupakan nilai kemampuan berpikir kritis antara kelas eksperimen yang menggunakan modul pembelajaran berbasis Guided Inquiry dengan kelas kontrol yang menggunakan metode konvensional. Data yang digunakan untuk hipotesis adalah gain score yang diperoleh dari selisih skor postest dan skor pretest. Perhitungan gain score disajikan pada tabel 1 .

Tabel 1.Kemampuan awal, kemampuan akhir dan gain score kemampuan berpikir kritis mahasiswa

\begin{tabular}{|l|c|l|}
\hline $\begin{array}{l}\text { Nilai Rata- } \\
\text { rata }\end{array}$ & Kelas kontrol & $\begin{array}{l}\text { Kelas } \\
\text { eksperimen }\end{array}$ \\
\hline $\begin{array}{l}\text { Kemampuan } \\
\text { awal }\end{array}$ & 62,02 & 63,54 \\
\hline $\begin{array}{l}\text { Kemampuan } \\
\text { akhir }\end{array}$ & 70,24 & 74,39 \\
\hline Gain score & 8,96 & 10,85 \\
\hline
\end{tabular}

Tabel 1 di atas menunjukkan bahwa dapat dilihat mahasiswa kedua kelas memiliki nilai Awal yang tidak jauh berbeda $(1,52)$. Akan tetapi, setelah penelitian perbedaan nilainya menjadi lebih tinggi, dimana perbedaannya antara kelas eksperimen dan kelas control adalah 4,15. Dengan kata lain, gain score kelas eksperimen lebih tinggi dibandingkan dengan kelas kontrol. Nilai Gain score kelas eksperimen sebesar 10,85 sedangkan kelas kontrol sebesar 8,96. Ini berarti modul pembelajaran berbasis guided inquiry berpengaruh terhadap kemampuan berpikir kritis mahasiswa.

Sebelum dilakukan uji beda rata-rata dua set data, dilakukan uji normalitas dan uji homogenitas varians. Dari kedua uji tersebut, ditemukan bahwa kedua set data berdistribusi secara normal dan bersifat homogen. Hasil Pretest-dan postest kemampuan berpikir Kritis mahasiswa di Kelas Eksperimen adalah seperti yang terlihat pada Tabel 2. 
Tabel 2. Hasil Uji Perbedaan Dua Rata-rata Data Hasil Pretest dan postest kemampuan berpikir kritis mahasiswa di Kelas Eksperimen

Paired Samples Test

\begin{tabular}{|c|c|c|c|c|c|c|c|c|}
\hline & \multicolumn{5}{|c|}{ Paired Differences } & \multirow{3}{*}{$\mathrm{t}$} & \multirow{3}{*}{$\mathrm{df}$} & \multirow{3}{*}{$\begin{array}{l}\text { Sig. } \\
\text { (2- } \\
\text { tailed) }\end{array}$} \\
\hline & \multirow[t]{2}{*}{ Mean } & \multirow[t]{2}{*}{$\begin{array}{l}\text { Std. } \\
\text { Deviation }\end{array}$} & \multirow[t]{2}{*}{$\begin{array}{l}\text { Std. } \\
\text { Error } \\
\text { mean }\end{array}$} & \multicolumn{2}{|c|}{$\begin{array}{l}\text { 95\% Confidence } \\
\text { Interval of the } \\
\text { Difference }\end{array}$} & & & \\
\hline & & & & Lower & Upper & & & \\
\hline $\begin{array}{l}\text { Pair } 1 \text { sebelum } \\
\text { - sesudah }\end{array}$ & $-1.085327 \mathrm{E} 1$ & 6.41312 & 1.00156 & 12.87789 & $\begin{array}{l}- \\
8.82943\end{array}$ & $\begin{array}{c}- \\
10.837\end{array}$ & 40 & .000 \\
\hline
\end{tabular}

Berdasarkan tabel 2, p-value sig (1- berbasis Guided Inquiry dapat meningkatkan tailed) yang diperoleh kurang dari 0,05. kemampuan berpikir kritis mahasiswa secara Dengan Demikian modul pembelajaran signifikan pada praktikum Kimia Dasar. Tabel 3. Hasil uji Perbedaan Dua Rata-rata data hasil Pretest dan Postest Kemampuan berpikir kritis mahasiswa kelas control

Paired Samples Test

\begin{tabular}{|c|c|c|c|c|c|c|c|c|}
\hline & \multicolumn{5}{|c|}{ Paired Differences } & \multirow{3}{*}{$t$} & \multirow{3}{*}{$\mathrm{df}$} & \multirow{3}{*}{$\begin{array}{l}\text { Sig. } \\
(2- \\
\text { tailed })\end{array}$} \\
\hline & \multirow[t]{2}{*}{ Mean } & \multirow[t]{2}{*}{$\begin{array}{l}\text { Std. } \\
\text { Deviation }\end{array}$} & \multirow[t]{2}{*}{$\begin{array}{l}\text { Std. } \\
\text { Error } \\
\text { mean }\end{array}$} & \multicolumn{2}{|c|}{$\begin{array}{l}\text { 95\% Confidence } \\
\text { Interval of the } \\
\text { Difference }\end{array}$} & & & \\
\hline & & & & Lower & Upper & & & \\
\hline $\begin{array}{l}\text { Pair } 1 \text { sebelum - } \\
\text { sesudah }\end{array}$ & -8.21429 & 5.15863 & .79599 & $\begin{array}{l}- \\
9.82183\end{array}$ & -6.60674 & $\begin{array}{l}- \\
10.320\end{array}$ & 41 & .000 \\
\hline
\end{tabular}

Hasil perhitungan uji perbedaan dua rata berpikir kritis mahasiswa yang memperoleh -rata data hasil pretest dan postest di kelas pembelajaran dengan menggunakan modul kontrol memiliki sig(1-tailed) yang diperoleh pembelajaran berbasis guided inquiry lebih kurang dari 0,05. Hasil ini menujukkan baik dibandingkan yang memperoleh bahwa pembelajaran konvensional dapat pembelajaran konvensional. Hasil uji meningkatkan kemampuan berpikir kritis perbedaan dua rata - rata postest kelas mahasiswa secara signifikan pada praktikum eksperimen dan kelas kontrol secara jelas Kimia Dasar. Peningkatan kemampuan dilihat pada tabel 4

Tabel 4. Uji Dua Rata - rata kelas eksperimen dan kelas kontrol.

Independent Samples Test

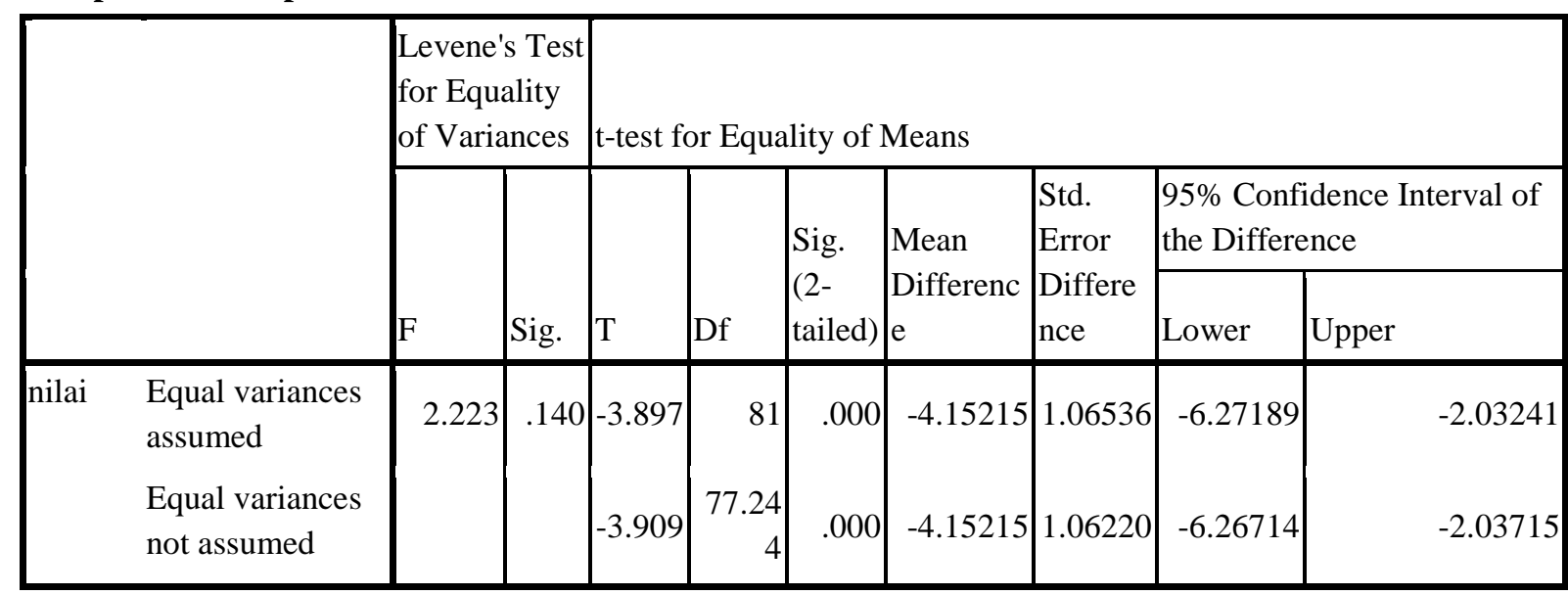


Hasil uji perbedaan dua rata - rata postest kemampuan berpikir kritis di kelas eksperiment dan kontrol memiliki sig. (2 tailed) 0,000. Dapat disimpulkan bahwa peningkatan kemampuan berpikir kritis mahasiswa pada praktikum Kimia Dasar lebih tinggi pada pembelajaran Guided Inquiry.

\section{Tabel 5. Hasil Observasi Kelas Eksperimen dan Kelas Kontrol}

\begin{tabular}{|c|l|l|l|l|l|}
\hline NO & \multicolumn{1}{|c|}{ Kategori } & Rata-rata (\%) & \multicolumn{2}{|c|}{ Kategori } \\
\cline { 3 - 6 } & \multicolumn{1}{|c|}{ Indikator Aktivitas } & $\begin{array}{l}\text { Kontrol } \\
(\%)\end{array}$ & & \\
\hline 1 & $\begin{array}{l}\text { Mahasiswa memperhatikan } \\
\text { penjelasan dosen dan materi } \\
\text { yang terdapat dalam modul } \\
\text { praktikum sebelum praktikum } \\
\text { dimulai }\end{array}$ & 64,3 & Cukup baik & 93,9 & Sangat baik \\
\hline 2 & $\begin{array}{l}\text { Mahasiswa fokus melakukan } \\
\text { kegiatan praktikum }\end{array}$ & 53,3 & $\begin{array}{l}\text { Kurang } \\
\text { baik }\end{array}$ & 75,6 & Baik \\
\hline 3 & $\begin{array}{l}\text { Mahasiswa bertanya kepada } \\
\text { dosen tentang materi yang akan } \\
\text { dipelajari }\end{array}$ & 26,2 & Tidak baik & 56,1 & Cukup Baik \\
\hline 4 & $\begin{array}{l}\text { Mahasiswa melakukan setiap } \\
\text { langkah praktikum dengan teliti }\end{array}$ & 41,6 & $\begin{array}{l}\text { Kurang } \\
\text { baik }\end{array}$ & 60,9 & Kurang baik \\
\hline 5 & $\begin{array}{l}\text { Mahasiswa membuat hasil } \\
\text { pengamatan dan terlibat aktif } \\
\text { dalam menyimpulkan hasil } \\
\text { praktikum baik }\end{array}$ \\
\hline
\end{tabular}

Dari Tabel diatas dapat digambarkan berpikir kritis mahasiswa secara signifikan bahwa aktivitas di kelas Eksperimen lebih baik dibandingkan dengan kelas kontrol. Dari Nilai Hasil perhitungan uji perbedaan dua rata -rata data masing - masing hasil pretest dan postest di kelas kontrol dan eksperimen memiliki sig (1-tailed) yang diperoleh kurang dari 0,05.

Hasil ini menunjukkan bahwa pembelajaran konvensional dan menggunakan modul pembelajaran samasama dapat meningkatkan kemampuan

\section{Hasil Observasi Aktivitas Mahasiswa} Kelas Kontrol dan Kelas Eksperimen

Untuk melihat aktivitas mahasiswa selama praktikum Kimia Dasar digunakan lembar observasi. Hasil aktivitas mahasiswa dapat dilihat dalam tabel 5 berikut pada praktikum Kimia Dasar. Hasil uji perbedaan dua rata- rata postest kemampuan berpikir kritis di kelas eksperiment dan kontrol memiliki sig. (2-tailed) 0,000. Dengan demikian pembelajaran dengan menggunakan model pembelajaran Guided inquiry lebih baik dalam meningkatkan kemampuan berpikir kritis mahasiswa pada praktikum Kimia Dasar.

Hal ini pada kelas eksperimen tahapan pembelajarannya ada tahap 
eksplorasi merupakan tahap mahasiswa mengumpulkan dan menganalisis data secara berkelompok. Pada tahap ini mahasiswa mengeksplorasi dan menganalisis beberapa variabel dalam bentuk data, tabel, grafik, dan lain-lain. Tahap pembentukan konsep merupakan tahap dimana dosen membimbing mahasiswa berdiskusi untuk mengenalkan konsep dan menginterpretasikan data. Mahasiswa menggunakan data yang telah didapatkannya selama tahap eksplorasi untuk mengembangkan sebuah konsep. Tahap aplikasi merupakan tahap mahasiswa menggunakan konsep yang telah didapatkan untuk melakukan aktivitas baru seperti mengerjakan latihan dan soal. Sehingga mahasiswa menjadi lebih aktif dan giat selama dalam praktikum, mahasiswa aktif menemukan konsep melalui kegiatan praktikum yang dilakukan.

Dari Tabel di atas dapat digambarkan bahwa aktivitas mahasiswa pada kelas Eksperimen lebih baik daripada yang kelas kontrol. Hal ini terlihat dari aktivitas mahasiswa di kelas eksperimen lebih baik dibandingkan dengan aktifitas mahasiswa di kelas Kontrol, seperti yang terlihat pada tabel 5. Adapun aktifitas mahasiswa memperhatikan penjelasan dosen, fokus selama praktikum dan bertanya selama proses praktikum dan melakukan tahapan praktikum dan bisa menyimpulkan hasil praktikum berdasarkan konsep-konsep yang didapatkan dalam praktikum. Hasil penelitian ini sejalan dengan hasil penelitian yang dilakukan oleh (Puspita \& Jatmiko, 2013; dan Kurniawati, Wartono, \& Diantoro, 2014)

\section{KESIMPULAN}

Dari uraian-uraian di atas dapat disimpulkan bahwa:

1. Kemampuan berpikir kritis mahasiswa meningkat secara signifikan setelah diajar menggunakan modul pembelajaran inkuiri terpimpin atau guided inquiry.

2. Kemampuan berpikir kritis mahasiswa meningkat secara signifikan pada pembelajaran konvensional.

3. Peningkatan kemampuan berpikir kritis mahasiswa dengan menggunakan model pembelajaran guided inquiry lebih tinggi dari pembelajaran konvensional.

4. Aktivitas mahasiswa terhadap pembelajaran menggunakan modul pembelajaran berbasis guided inquiry pada mata kuliah Kimia Dasar lebih baik dibandingkan dengan pembelajaran konvensional.

\section{REFERENSI}

Arikunto, Suharsimi. 2013. Dasar-dasar Evaluasi Pendidikan. Jakarta: Bumi Aksara

Branch, Robert Maribe. 2009. Instructional Design: The ADDIE Approach. New York: Springer

Boslaugh, Sarah dan Paul A. W. (2008). Statistics in a Nutshell, a desktop quick reference. Beijing, Cambridge, Famham, Köln, Sebastopol, Taipei,Tokyo: O'reilly.

Depdiknas. 2008. Pengembangan Bahan Ajar. Jakarta: Departemen Pendidikan Nasional, Direktorat Jenderal Manajemen Pendidikan Dasar dan Menengah, Direktorat Pembinaan Sekolah Menengah Atas. 
Hamalik, Oemar. 2001. Proses Belajar Mengajar. Jakarta: Bumi Aksara

Kemendiknas. 2010. Juknis Pengembangan Bahan Ajar SMA. Jakarta : Direktorat Pembinaan SMA.

Mudjijo. 1995. Tes Hasil Belajar. Jakarta: BumiAksara.

Nasution, S.2011. Berbagai Pendekatan dalam Proses Belajar dan Mengajar. Jakarta: BumiAksara.

Prastowo, Andi. 2011. Panduan Kreatif Membuat Bahan Ajar Inovatif. Yogyakarta: Diva Press. Prinsip dan Teknik Evaluasi Pengajaran

Puspita, A. T., \& Jatmiko, B. (2013). Implementasi Model Pembelajaran Inkuiri Terbimbing ( Guided Inquiry ) terhadap Keterampilan Berpikir Kritis Siswa pada Pembelajaran Fisika Materi Fluida Statis Kelas XI Di SMA Negeri 2
Sidoarjo. Jurnal Inovasi Pendidikan Fisika, 2(3), 121-125.

Sadiman, Arief. S. 2003. Media Pendidikan. Jakarta: PT Raja Grafindo Persada

Sudjana, Nana. 2001. Penilaian Hasil Proses Belajar Mengajar. Bandung: Remaja Rosdakarya

Sudijono, Anas. 2007. Pengantar Evaluasi Pendidikan. Jakarta: PT Raja Grafindo Persada

Sugiyono. 2006. Metode Penelitian Pendidikan Pendekatan Kuantitatif, Kualitatif, dan $R$ \& $D$. Bandung: Alfabeta.

The College Board. 2012. AP ${ }^{\circledR}$ Chemistry Guided-Inquiry Experiments: Applying the Science Practices (Teacher Manual). New York: The College Board.

Winkel, WS. (1996). Psikologi Pengajaran. Jakarta: Gramodul

\section{Article Metadata:}

Marisa. Pradisa, L. (2018). The Effect of Guided Inquiry Module Use on Students' Critical Thinking at Stikes Perintis Padang. Ta'dib, 21 (2), 113-120 http://dx.doi.org/10.31958/jt.v21i2.1194

Keywords: Module, guided inquiry, critical thinking ability Coresponding author: Marisa, STIKes Perintis Padang, marisaazzhila@yahoo.co.id 